\title{
VOLUNTEERED GEOGRAPHIC INFORMATION (VGI) APPLICATION FOR MONITORING LAND USE VIOLATION CASE STUDY: CIGANJUR FLOOD
}

\author{
Bayu Purwanto ${ }^{1 *}$, Anang Wahyu Sejati ${ }^{2}$ \\ 1,2 Diponegoro University \\ Jl. Prof. Sudarto No.13, Tembalang, Semarang City, Central Java 50275, Indonesia \\ extraman906@gmail.com¹, anang@live.undip.ac.id ${ }^{2}$
}

(*) Corresponding Author

\begin{abstract}
Abstrak
Ruang di DKI Jakarta memiliki masalah dalam hal pemanfaatannya. Banyak pemanfaatan ruang yang tidak sesuai dengan rencana tata ruang. Bangunan ilegal banyak ditemui di kawasan peruntukan ruang terbuka hijau maupun sempadan sungai. Pemantauan terhadap pelanggaran pemanfaatan ruang membutuhkan peran teknologi informasi. Penelitian ini menggunakan aplikasi berbasis open source sehingga lebih mudah dan murah dalam pengembangannya. Aplikasi terdiri dari aplikasi berbasis smartphone untuk proses pelaporan pelanggaran ruang dengan konsep Volunteered Geographic Information (VGI). Aplikasi dapat secara langsung menganalisis data yang telah terverifikasi dengan rencana tata ruang. Analisis menggunakan analisis overlay untuk melihat lokasi dan luas pelanggaran pemanfaatan ruang. Hasil dari analisis dapat dijadikan dasar pertimbangan bagi pemerintah daerah untuk memberikan sanksi terhadap bangunan ilegal dan untuk merencanakan kota di masa depan.
\end{abstract}

Kata kunci : Open Source, Overlay, Pelanggaran ruang, Smartphone, Tata ruang, VGI

\begin{abstract}
Land in DKI Jakarta has problems in land use. Many land-use does not comply with planning. Illegal buildings are often found in areas designated for green open space and river boundaries. Land use monitoring requires the role of information technology. This research uses an open-source-based application to develop easier and cheaper. The application consists of a smartphone-based application for the process of reporting land-use violations with the concept of Volunteered Geographic Information (VGI). The application can directly analyze verified data with spatial planning. The analysis uses overlay analysis to see the location and extent of violations in land use. The results of the analysis can be used as a basis for local governments to impose punishment on illegal buildings and to plan for future cities.
\end{abstract}

Keywords- Open Source, Overlay, Smartphone, Spatial planning, VGI, Violation.

\section{INTRODUCTION}

DKI Jakarta Province, the capital city of the Republic of Indonesia, has five administrative cities with an area of $662 \mathrm{Km} 2$ (Kusumo et al. 2017). Ciganjur village belongs to the administrative area of South Jakarta City. Located in the south of Jakarta and bordering Depok City with the Krukut River. The topography of Ciganjur Village has a low slope angle. The slope level is between $0-8 \%$ with an altitude between 36 - 66 meters above sea level. The highest area is located quite far from the krukut river and the lowest area is the krukut river border area. Before 2020 the Ciganjur Village had never been affected by widespread flooding and caused loss of material nor decease to the community. However, in October 2020, floods inundated several areas in Ciganjur Village, even causing landslides. So it is necessary to analyze the causes of flooding in Ciganjur Village.

Floods in Jakarta generally occur due to people's behavior (Neolaka. 2012). Illegal buildings along the river are found in Jakarta. This is getting worse by the attitude of the people who do not care about the buildings along the river (Neolaka. 2012). Land-use change where green open space is running low will increase the risk of flooding (Abass et al. 2020). DKI Jakarta adopted a land regulation that states that the area of urban green open space is 30\%, however, only $7.61 \%$ was able to be realized in 2017 
(Muhajir. 2017). Land use in DKI Jakarta Province is regulated in Regional Regulation No. 1 of 2012 concerning the 2010-2030 Jakarta Regional Spatial Planning. The plan for river border areas and green open spaces is stated in the regulation. According to CEN, the river boundary area is recommended for $50 \mathrm{~m}$ on both sides (Kujanová et al. 2018). River border areas in Indonesia are regulated through Minister of Public Works and Housing Regulation No. 28/2015 with a minimum length of $15 \mathrm{~m}$ for rivers with a depth of more than $3 \mathrm{~m}$. The Jakarta Regional Spatial Plan assigns the boundary area along the Krukut River is $20 \mathrm{~m}$.

Volunteered Geographic Information (VGI) is needed for the public reporting process regarding land use violations. VGI is spatial information that uses the community as a network in its collection (Jelokhani-Niaraki et al. 2019). VGI provides the required information at a cost that is not expensive (Stehman et al. 2018). Implementing VGI is using information technology. Information technology is useful for developing smart governance according to community needs (Sejati et al. 2020). People, in general, are familiar with the use of smartphones. Popularity and ease of access are the main considerations for using a smartphone as media of VGI. Data verification is an issue in the application of VGI. Verification requires a comparison of data from VGI with characteristic data in the field (Stehman et al. 2018). VGI verified data can provide real-time information on the extent of land-use violations.

Several previous studies have utilized VGI for various purposes. VGI can be used as a participatory tool to create an elderly-friendly city, establish disaster posts, and report spatial planning violations (Jelokhani-Niaraki et al. 2019; Kusumo et al. 2017; Sejati et al. 2020). Jelokhani-Niaraki uses VGI as a tool of participation in determining an elderly-friendly city. Citizens and experts provide recommendations in the form of geographic location and will be used as input for determining the location of an elderly-friendly city. Kusumo used VGI to determine the location of flood evacuation through the spatial pattern from Twitter. Sejati made an application to report spatial planning violations in Balikpapan City. VGI geometry in several of those studies is the point. It is difficult to analyze in area. Spatial planning is area-based so it requires area analysis. This research will use VGI with polygon geometry so that the area of the spatial planning violation can be analyzed.

VGI application design uses open source. The advantage of using open source is that the application can be used for free. Open source also provides a collaboration forum for each developer.
Collaboration can detect application bugs, improve and develop software products (Wang et al. 2015).

\section{RESEARCH METHODS}

The purpose of control is to ensure that the implementation process is carried out by spatial planning, corrects irregularities, and produces objectives according to the plan (Muhajir. 2017). The role of controlling spatial use is very important to ensure land use and maintain environment quality so that development can be suitable with sustainable principles. The process of controlling land use requires a platform for the reporting function by the public and controlled by the governor. The best platform is web-based. The webbased system will have the advantage in terms of accessibility. Web-based systems can be accessed via laptop, smartphone, and computer making them easy to access anywhere.

This study presents the VGI reporting process for land use in two platforms, namely mobile-based applications, and web-based applications. Mobile-based applications are used for reporting on land use from the community. The web-based application is used as a supervisory dashboard by the governor and local government.

\section{A. Flood in Indonesia}

Flood is a disaster because the space for water absorption is not sufficient, and water inundates areas that are not intended for water flow (Qodriyatun. 2020). The factors causing flood according to Yulaelawati (2008) are human activities such as violations of spatial planning, geographical conditions such as river areas that are prone to flooding, and dynamic natural factors such as rainfall.

Flood disaster in Indonesia is caused by the incompatibility of spatial use with spatial planning (Qodriyatun. 2020). Building in river borders will obstruct the river flow conditions, sediments, and natural vegetation (Kujanová et al. 2018). Vegetation effects reducing the rate of erosion and stability of landforms (Hupp \& Osterkamp. 1996). The loss of vegetation on river areas due to violation use of space will increase the risk of flooding.

Urban development is one of the causes of flooding (Abass et al. 2020). Rapid urban development will reduce green open space. Landuse change from green open space can be analyzed using the GIS method to see the level of green open spaces availability in urban areas. The distribution of green open space is also adjusted to the quantity and accessibility (Hwang et al. 2020). Quantity can be interpreted as the green open space must be 
balanced and can support urban functions. The purpose of accessibility is accessible to all urban communities. Violations of green open space can cause environmental imbalances. This will increase the risk of flooding.

\section{B. Voluntereed Geographic Information (VGI)}

The public role in the spatial planning process is very important. Space is a place for people to do social and economic activities (Pratomo et al. 2019). Public participation in the monitoring and evaluation process has a dominant influence on social sustainability (Kibukho. 2021). Public participation in spatial planning can use the principle of the community as the main actor, the government as a facilitator, respecting the rights and social culture of the community, the principle of openness, and technological developments (Despica. 2017). A participatory approach will give people the opportunity to control their own lives and be able to map their surroundings (Kibukho. 2021). Barriers to the role of the community in urban spatial planning are late community participation after the plan is prepared, community participation is minimal, input from the community is minimal, time for public discussion is limited, and there is no space or forum for the community to express their aspirations (Adiyanta. 2018).

One of the technologies that can be used as a forum for the community to express their aspirations is VGI. VGI is a tool for obtaining, managing, and disseminating spatial data obtained voluntarily and individually (Goodchild. 2007). VGI is inexpensive data in the context of remote sensingbased land cover monitoring (Stehman et al. 2018) VGI is a new approach to the production of spatial data where spatial data from VGI can be utilized through existing geoportal (Elwood. 2008). Utilization of technology VGI can be the form of geolocation in social media applications such as Twitter and Open Street Map (Schade et al. 2013). In this study VGI by utilizing the Global Positioning System (GPS) on a smartphone to get coordinates from the community. VGI reporting by open-source leaflet library to input polygon data on spatial planning violations.

The basic knowledge and skills of the community in inputting different spatial data make VGI data need to be checked or verified (Elwood. 2008). The purpose of verification is to maintain the high quality of VGI data (Yan et al. 2017). In this study, the quality control of the VGI data is carried out through a verification process by the user who as a verification. The verification will compare the VGI data with the data in the field. If the VGI report is by the conditions in the field, the data will become official data on spatial planning violations.

Smartphones are very popular in society. Almost all urban communities have smartphones. The use of smartphones for VGI-based reporting processes is intended to reach wide participation. Some studies argue that smartphone users are very strategic and rational (Kujanová et al. 2018). The development of smartphone technology, especially GPS, makes crowdsourcing based on map can applicable.

The programming language used to build a smartphone-based system is flutter. Flutter is Google's programming language for creating mobile-based applications. Flutter is used to build applications natively with the Dart programming language. In this study, flutter is the basis of a smartphone-based VGI reporting application.

Reporting data from the public is stored in service format. Service is built and managed by Geoserver. Geoserver is a Java-based open-source software that allows users to create, edit and share spatial data. The use of service-based data is to make reporting effective and efficient. The VGI application does not require storage media on a smartphone because the reporting data will be directly stored as a service. So that the VGI application will not burden the smartphone of the user.

\section{WebGIS Based on Open Source}

In this study, WebGIS is used for verification media and dissemination of reporting results from the public. WebGIS is a GIS application that resides on the internet network and can disseminate geospatial information on a web platform (Wang et al. 2015). The concept of webGIS is to provide spatial information to support the decision-making process (Sejati et al. 2020). WebGIS can run better if its functionality and performance can be defined before development. WebGIS based on open source can be implemented because the cost is low and the goal of open data can be achieved (Sejati et al. 2020).

Open-source software is used to support application development with minimum costs. Open source software used in building GIS-based applications is suitable with Open Geospatial Consortium (OGC) organization. OGC sets standards for the dissemination of spatial data, it is Web Feature Service (WFS), Web Map Service (WMS) and Web Coverage Service (WCS)(Singh et al. 2019). 


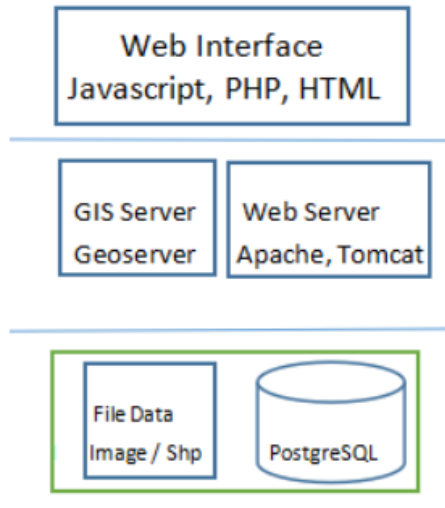

Figure 1 VGI WebGIS Architecture System

Figure 1 is a VGI webGIS architectural system design by utilizing open-source software support. At the data layer, the storage media uses a PostgreSQL database with the PostGIS extension to store spatial data. The application layer consists of two servers, a GIS Server using GeoServer for the dissemination of spatial data according to OGC standards and a web server using apache and tomcat. At the presentation layer, the application is built using the leaflet library and combined with PHP and HTML.

\section{Spatial Query}

A spatial query is a query for data based on spatial characteristics. Spatial queries support the use of point, line, and polygon geometries as input queries (Nguyen. 2009). The result of the spatial query will be in the form of spatial data with the point, line, or polygon geometry. Spatial queries are supported by a geodatabase structure (Nguyen. 2009). The language used in spatial queries is a structured query language (SQL). SQL is used to search and retrieve data from a database. Some of the spatial queries supported by OGC are :

1. Spatial measurements: to calculate the distance between points, lines, and polygons.

2. Spatial functions: for analyzing spatial data, such as buffer, union, and intersect the data.

3. Spatial predicates: for queries with true/false results.

4. Constructor functions: to create new features from SQL query results.

5. Observer functions: to return the specific location of a feature, such as the location of the center of the circle.

The Global Positioning System (GPS) can be combined with Geographic Information System (GIS) technology and remote sensing to create realtime, efficient, and practical spatial data (Yan et al. 2017). GPS data is coordinate data in point format.
Spatial queries can be used on GPS data and combined with other spatial data for specific purposes

Figure 2 is the use of spatial query in the process of reporting land-use violations from the community. The GPS of the user will detect the coordinates of the user's location. These coordinates are represented as point geometry. Coordinates are used for the spatial query process on the spatial planning map of DKI Jakarta Province. The result of the spatial query is in the form of polygon geometry from the spatial planning map where the user's location is located. Planning of the space at the user's location can be known.

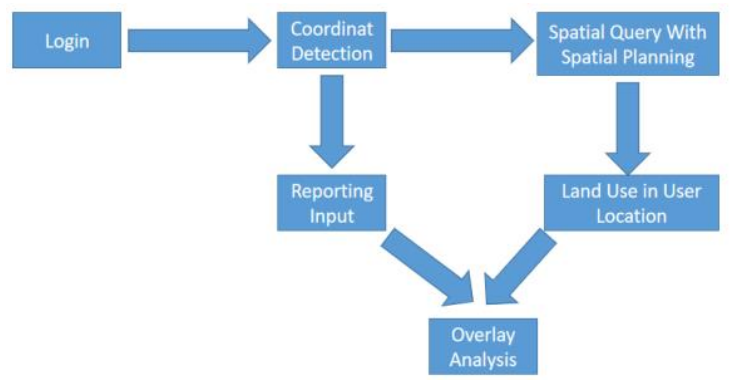

Figure 2 Flow of Spatial Query Usage in VGI System

\section{E. Overlay Analysis}

Overlay analysis is a spatial operation by combining or comparing different geographic layers to obtain new information (Larasati et al. 2017). Overlay analysis is used to analyze the spatial correlation between two or more spatial data. Overlapping data on land use in one location can be identified. The data structure for overlay analysis is recommended to have the same scale. The same scale will make the feature level detail is the same. Overlay analysis processing takes quite a long time (Wang et al. 2015). Therefore, the use of overlay analysis must be carried out properly, both algorithms and determination of the software used for analysis.

The most commonly used overlay analyzes are intersection, union, and identity. This research uses intersection analysis. Intersect analysis is the process of combining two sets of spatial data and generating new information in the form of data that is within the extent of the two data (Stehman et al. 2018). Input data for Intersect analysis can be points, lines, or polygons. Intersect analysis can be used in several GIS software such as ArcGIS and QGIS. Intersect analysis in this study is based on web programming. The application will automatically intersect two polygon data, it is VGI data and spatial planning map. To facilitate webbased intersect analysis, postgreSQL software with postGIS extension is used. PostGIS provides two 
functions to perform intersection analysis. The two functions are st_intersects and st_intersection. The use of the SQL language in PostGIS makes it possible to do web-based intersect analysis.

This study uses overlay analysis by performing intersect operations on verified VGI data with a spatial planning map. Overlay analysis is performed for each sector. The results of the overlay analysis are space violation data in each sector. Information on the extent of violations and a large number of spatial violations can be the basis for analysis causes of flooding in Ciganjur Village.

\section{RESULTS AND DISCUSSION}

\section{A. Android-based of VGI}

The VGI application has the main function as a media for reporting a land-use violation in Ciganjur Village, DKI Jakarta Province. This application can be run on the smartphone media from the public. The public can easily access the VGI application anywhere.
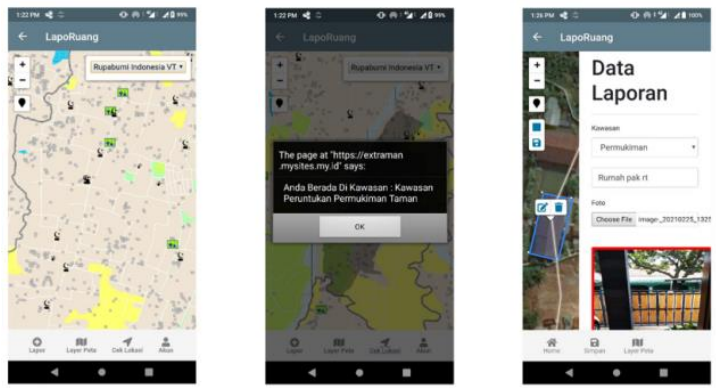

Figure 3 Implementation of Android Based VGI Applications

Figure 3 is the result of implementing the VGI application that has been installed on smartphone media. The VGI application uses topographic maps of Indonesia from the Geospatial Information Agency, Open Street Map, and satellite imagery from ESRI. The base map is used as the basis for digitizing polygons in the reporting menu. Land use violations can be reported by first detecting the spatial planning at the user's location (figure in the middle). If the spatial planning is not by the development in the field, then the user can report the violation. VGI reporting is accompanied by a photo to facilitate verification from the local government (figure at the end).

\section{B. Web-Based Verification System}

The data reported by the public on the Android-based VGI system needs to be verified.
Verification by comparing reporting data with field data. Verification using a web-based system.

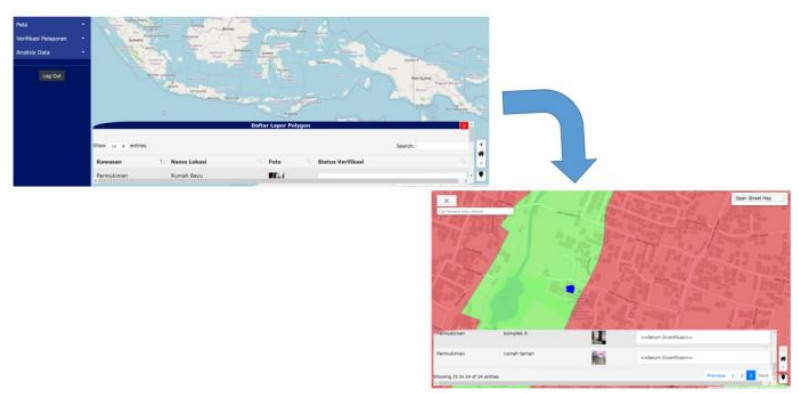

Figure 4 Implementation of Web-Based VGI Verification

Figure 4 is the result of the implementation of webbased VGI verification. The information and geometry can be seen from all reporting data from the public. Verification by comparing with the base map, satellite imagery, and spatial plan map of DKI Jakarta. If the reporting of violation is geometrically compatible with the base map and by the realities in the field, the report can be approved. The report status can be known by the reporter. Reports that are rejected during the verification process can be corrected by the reporter.

\section{Web-Based Dashboard System}

The dashboard system is an analysis of reporting data. The dashboard system can be used as a monitoring platform for the Governor of DKI Jakarta against spatial violation in his area. The analysis is displayed graphically and on a map.
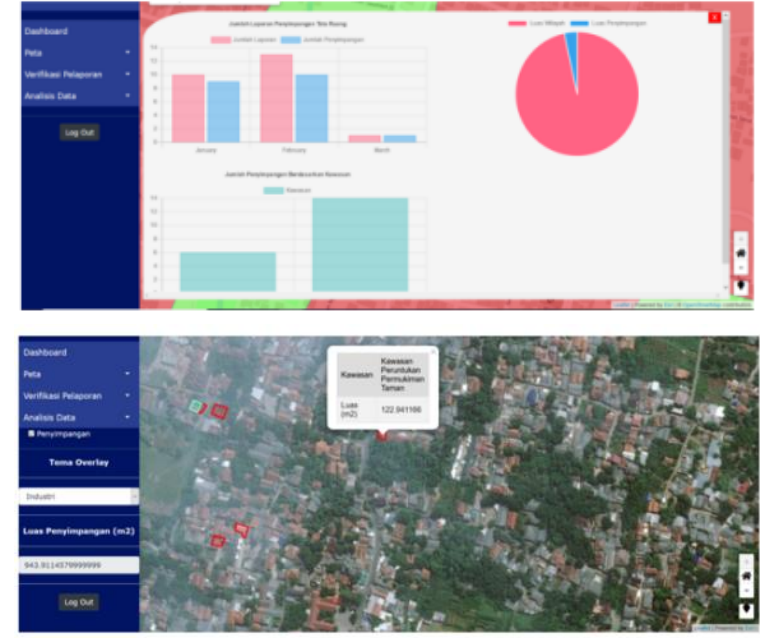

Figure 5 Implementation of Web-Based VGI Dashboard

Figure 5 is the result of the analysis implementation which is presented in the form of a dashboard. Statistical analysis to determine the number of 
reports each month, the number of violations per sector, and the extent of violations that occur. The spatial analysis presents a map and the extent of violations in each sector.

Time load to access the VGI application can be seen in Figure 6. The results of the analysis show that the number of users has no significant effect on the speed of application access. The algorithm and server used were able to provide an access time of about 1 second for testing up to 60 users.

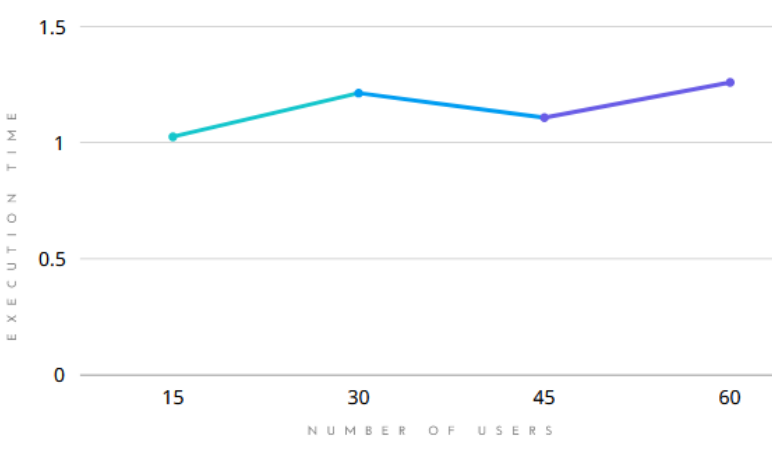

Figure 6 Time Load to Acess VGI Application Based on Number of Users

The web-based analysis used is overlay analysis. This analysis tested based on the number of space violation records. Figure 7 is the result of the test. It can be seen that the higher number of space violation reports, the slower the web-based overlay analysis time will be. So that the potential execution time will be slower in line with the increasing number of reports of spatial violations from the public.

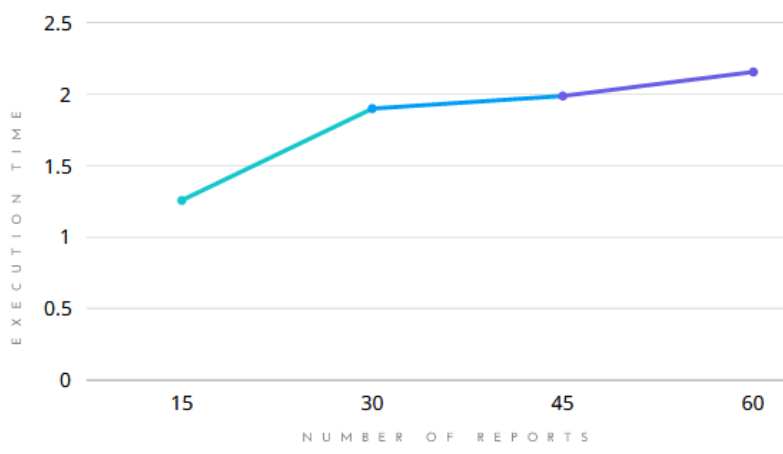

Figure 7 Time Load to Analysis Based on Number of Records

\section{CONCLUSIONS AND SUGGESTIONS}

Based on the results of the study, the development of the VGI application and spatial violation dashboard can help the community participation process through a smart government system. The application that is built is open source so it does not require expensive costs. VGI can be used to detect land-use violations in Ciganjur Village, DKI Jakarta. VGI provides a geometry that can be calculated in real-time the area of the violation. The VGI application can help quickly see a violation in each sector. The public can report landuse violations such as buildings on river boundaries. Based on VGI data, the Governor can implement punishment against buildings that do not comply with the spatial planning. So that the spatial balance in Ciganjur and DKI Jakarta can be maintained. The bad effects of environmental imbalances such as flooding can be minimized. DKI Jakarta can apply the concept of a sustainable city.

The results of the application test based on the number of users give the result that the application was able to return requests in a fast time up to 60 users. This means that the algorithms and servers used are capable to accommodate many users. While the web-based analysis test based on the number of violations reports stated that the more reports the slower the application performance. Overlay analysis execution time is directly proportional to the number of space violation reports. This is because the number of space violation reports is stored as a record in the table. The more records in a table the more loops that must be done for each overlay analysis. Some system adjustments for future work should be made, especially regarding the speed of the analysis. Therefore, future work is needed for the development of performance systems. Thus, it will accelerate the process of community participation in spatial planning.

\section{REFERENCES}

Abass, K., Buor, D., Afriyie, K., Dumedah, G., Segbefi, A. Y., Guodaar, L., Garsonu, E. K., AduGyamfi, S., Forkuor, D., Ofosu, A., Mohammed, A., \& Gyasi, R. M. (2020). Urban sprawl and green space depletion: Implications for flood incidence in Kumasi, Ghana. International Journal of Disaster Risk Reduction, 51(September), 101915. https://doi.org/10.1016/j.ijdrr.2020.1019 $\underline{15}$

Adiyanta, F. C. S. (2018). Partisipasi Masyarakat Sebagai Basis Kebijakan Penataan Ruang Publik dan Ruang Terbuka Hijau Kota yang Berkelanjutan. Administrative Law \& Governance Journal, 1(1), 1. https://doi.org/10.14710/alj.v1i1.1-8

Andrean, K., Armanto, H., \& C. Pickerling. (2020). Sistem Tempat Parkir Terintegrasi yang 
Dilengkapi dengan Aplikasi Mobile dan Mikrokontroller. Journal of Information System,Graphics, Hospitality and Technology, 2(01), 22-29. https://doi.org/10.37823/insight.v2i01.7 $\underline{9}$

Despica, R. (2017). Partisipasi Masyarakat Dalam Perencanaan Tata Ruang Daerah Untuk Pembangunan Wilayah Kota Padang. Jurnal Spasial, $1(2)$. https://doi.org/10.22202/js.v1i2.1577

Elwood, S. (2008). Volunteered geographic information: Future research directions motivated by critical, participatory, and feminist GIS. GeoJournal, 72(3-4), 173183. https://doi.org/10.1007/s10708008-9186-0

Fahrozi, W., \& Harahap, C. B. (2018). Sistem Informasi Transparansi Nilai Mata Kuliah Berbasis Web. Jurnal Sistem Informasi Ilmu Komputer Prima, 2(1), 56-62. http://jurnal.unprimdn.ac.id/index.php/I USIKOM/article/view/165

Goodchild, M. F. (2007). Citizens as sensors: The world of volunteered geography. GeoJournal, 69(4), 211-221. https://doi.org/10.1007/s10708-0079111-y

Hupp, C. R., \& Osterkamp, W. R. (1996). Riparian Vegetation and Fluvial Geomorphology. Geomorphology, 14, 277-295. https://doi.org/10.1029/WS008

Hwang, Y. H., Nasution, I. K., Amonkar, D., \& Hahs, A. (2020). Urban green space distribution related to land values in fast-growing megacities, Mumbai and Jakartaunexploited opportunities to increase access to greenery for the poor. Sustainability (Switzerland), 12(12). https://doi.org/10.3390/su12124982

Jelokhani-Niaraki, M., Hajiloo, F., \& Samany, N. N. (2019). A Web-based Public Participation GIS for assessing the age-friendliness of cities: A case study in Tehran, Iran. Cities, 95(August),

102471. https://doi.org/10.1016/j.cities.2019.102 $\underline{471}$

Kibukho, K. (2021). Mediating role of citizen empowerment in the relationship between participatory monitoring and evaluation and social sustainability. Evaluation and Program Planning, 85(January), 101911. https://doi.org/10.1016/j.evalprogplan.2 021.101911

Kujanová, K., Matoušková, M., \& Hošek, Z. (2018). The relationship between river types and land cover in riparian zones. Limnologica, 71(May), 29-43. https://doi.org/10.1016/j.limno.2018.05. $\underline{002}$

Kusumo, A. N. L., Reckien, D., \& Verplanke, J. (2017). Utilising volunteered geographic information to assess resident's flood evacuation shelters. Case study: Jakarta. Applied Geography, 88, 174-185. https://doi.org/10.1016/j.apgeog.2017.07 .002

Larasati, N. M., Subiyanto, S., \& Sukmono, A. (2017). Jurnal Geodesi Undip Oktober 2017. Analisis Penggunaan Dan Pemanfaatan Tanah (P2T) Menggunakan Sistem Informasi Geografis Kecamatan Banyumanik Tahun 2016, 6, 89-97.

Muhajir, A. (2017). Kebijakan Pengendalian Pemanfaatan Ruang dalam Pelaksanaan Ketentuan Penataan Ruang Di Kota Baubau Provinsi Sulawesi Tenggara. Jurnal Renaissance, 2(02), 184-193. http://www.ejournalacademia.org/index.php/renaissance

Neolaka, A. (2012). Flood disaster risk in Jakarta, Indonesia. WIT Transactions on Ecology and the Environment, 159, 107-118. https://doi.org/10.2495/FRIAR120091

Nguyen, T. (2009). Indexing PostGIS databases and spatial Query performance evaluations. In International Journal of Geoinformatics (Vol. 5, Issue 3, pp. 1-9).

Pratomo, A., Soedwiwahjono, S., \& Miladan, N. (2019). Kualitas Taman Kota Sebagai Ruang Publik Di Kota Surakarta Berdasarkan Persepsi Dan Preferensi Pengguna. Desa-Kota, 1(1), 84. https://doi.org/10.20961/desakota.v1i1.12494.84-95

Qodriyatun, S. N. (2020). Bencana Banjir: Pengawasan dan Pengendalian Pemanfaatan Ruang Berdasarkan UU Penataan Ruang dan RUU Cipta Kerja. Aspirasi: Jurnal Masalah-Masalah Sosial, 11(1), 29-42. https://doi.org/10.46807/aspirasi.v11i1.1 $\underline{590}$

Schade, S., Díaz, L., Ostermann, F., Spinsanti, L., Luraschi, G., Cox, S., Nuñez, M., \& De Longueville, B. (2013). Citizen-based sensing of crisis events: Sensor web enablement for volunteered geographic information. Applied Geomatics, 5(1), 318. https://doi.org/10.1007/s12518-0110056-y 
Sejati, A. W., Bukhori, I., Rudiarto, I., SILVER, C., \& SULISTYO, K. (2020). Open - Source Web Gis Framework in Monitoring Urban Land Use Planning: Participatory Solutions. Journal of Urban and Regional Analysis, XII, 19-33.

Singh, H., Garg, R. D., \& Karnatak, H. C. (2019). Online image classification and analysis using OGC web processing service. Earth Science Informatics, 12(3), 307-317. https://doi.org/10.1007/s12145-01900378-z

Stehman, S. V., Fonte, C. C., Foody, G. M., \& See, L. (2018). Using volunteered geographic information (VGI) in design-based statistical inference for area estimation and accuracy assessment of land cover. Remote Sensing of Environment, 212(February), https://doi.org/10.1016/i.rse.2018.04.01 $\underline{4}$

Wang, J., Shih, P. C., \& Carroll, J. M. (2015). Revisiting Linus's law: Benefits and challenges of open source software peer review. International Journal of Human-Computer Studies, 77, 52-65. https://doi.org/10.1016/j.ijhcs.2015.01.0 05

Yan, Y., Feng, C. C., \& Wang, Y. C. (2017). Utilizing fuzzy set theory to assure the quality of volunteered geographic information. GeoJournal, 82(3), 517-532. https://doi.org/10.1007/s10708-0169699-x

Yulaelawati, E., \& Syihab, U. (2008). Mencerdasi Bencana. Jakarta: PT. Grasindo. 47-59. 